Volume 3, Issue 1, pages 83-92

p-ISSN 2655-8564, e-ISSN 2685-9432

\title{
Effects of the Existence of Fan in the Wood Drying Room and the Performance of the Electric Energy Wood Dryer
}

\author{
Wibowo Kusbandono ${ }^{1, *}$, Petrus Kanisius Purwadi ${ }^{1}$ \\ ${ }^{1}$ Department of Mechanical Engineering, Faculty of Science \\ and Technology, Sanata Dharma University, Yogyakarta, Indonesia \\ *Corresponding Author: bowo@usd.ac.id
}

(Received 24-01-2021; Revised 05-02-2021; Accepted 21-03-2021)

\begin{abstract}
The purpose of this study is to determine the effect of the presence of a fan in the wood drying room in the drying time of wood. In addition, it is also to determine the performance of the steam compression cycle engine used in wood drying machines and the conditions of air entering and leaving the wood drying room. Wood drying machines work on a source of electrical energy. The research was conducted experimentally. Variations in the study were carried out on the presence of fans in the drying room: (a) there were no fans and (b) there were 2 fans. The dried object is a sengon wood board, which has a length of $2 \mathrm{~m}$, a width of $20 \mathrm{~cm}$, and a thickness of $2 \mathrm{~cm}$. The number of wooden planks is 70 wooden planks of uniform size. The wooden planks before drying have a moisture content of $29.6 \%$, and when dry, have a moisture content of $10 \%$. The research gave the following results: (a) if there are 2 fans in the drying room, the time needed to dry the sengon wood planks is around 42.6 hours, whereas if there is no fan around 49.9 hours (b) the average Coefficient of Performance (COP) of the steam compression cycle engine is 10.65 (c) The air condition enters the drying room when
\end{abstract}




\section{International Journal of Applied Sciences and Smart Technologies}

Volume 3, Issue 1, pages 83-92

p-ISSN 2655-8564, e-ISSN 2685-9432

there are 2 fans, has a dry ball air temperature of $40^{\circ} \mathrm{C}$ with a relative humidity of $32 \% \mathrm{RH}$ and the air condition when it comes out, has a dry ball air temperature of $28^{\circ} \mathrm{C}$ with a relative humidity of $73 \% \mathrm{RH}$.

Keywords: Wood drying machine, steam compression cycle, electricity, COP

\section{Introduction}

Wood is the main material in the furniture industry. Before being processed into finished goods, the wood must be dry. If it is not dry, the products can change shape into unwanted shapes. One of the problems that exist in the wood industry is how to dry wood that does not interfere with production. At this time, generally the wood drying process is carried out with the help of solar energy or with fuel energy from wood that is no longer used. For energy from wood fuel, besides being complicated, it is also not environmentally friendly. In addition, the time used for the drying process is long. So it needs careful calculations so that production is not disturbed by the absence of dry wood. The use of solar energy is more practical, more environmentally friendly, cheaper, with unlimited energy sources, free and available everywhere, but this method cannot be relied on when the rainy season arrives. Even though the rainy season lasts quite a long time. It is necessary to look for other alternatives, which are more practical, environmentally friendly and can be done anytime and anywhere. The solution is to use electrical energy.

Many studies related to the drying process with electrical energy have been carried out. A suitable solution for the use of electrical energy is to use a steam compression cycle machine. As has been done by these researchers, in the drying process. Steam compression cycle machine, used to produce dry and hot air. With dry and hot air, the object drying process can run well. In the research that has been done, the dried objects are different. Mitsunori [1] conducted research with the cloth object. Balioglu [2] and Bison [3] conducted research with the object of laundry. Kusbandono and Purwadi [4,5] conducted research with the object to be chilled. 


\section{International Journal of Applied Sciences and Smart Technologies}

Volume 3, Issue 1, pages 83-92

p-ISSN 2655-8564, e-ISSN 2685-9432

From the research that has been conducted by these researchers, a question arises for the authors, can the wood drying process be carried out using electrical energy involving a steam compression cycle machine. As it is known, that wood is a solid, dense, hard object, with a relatively large size, with a very low moisture content in the wood. Starting from this problem, the research was carried out.

\subsection{Steam Compression Cycle}

The main components of a steam compression machine include: compressor, condensor, capillary tube and evaporator. The working fluid used in the vapor compression cycle is a refrigerant. Figure 1 presents a series of main components of a steam compression engine and Figure 2 presents a simple vapor compression cycle shown on the $\mathrm{p}$-h diagram.

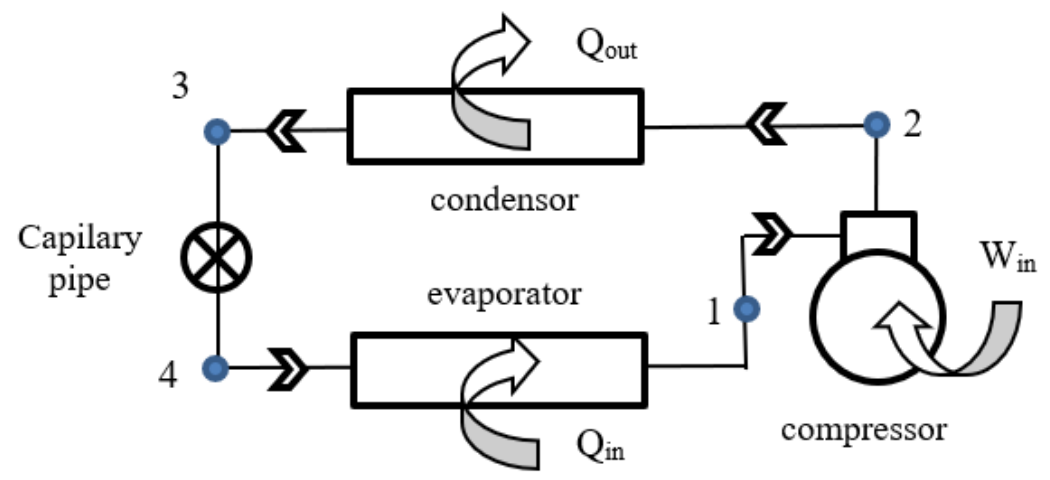

Figure 1. Circulation of the main components of a steam compression cycle engine

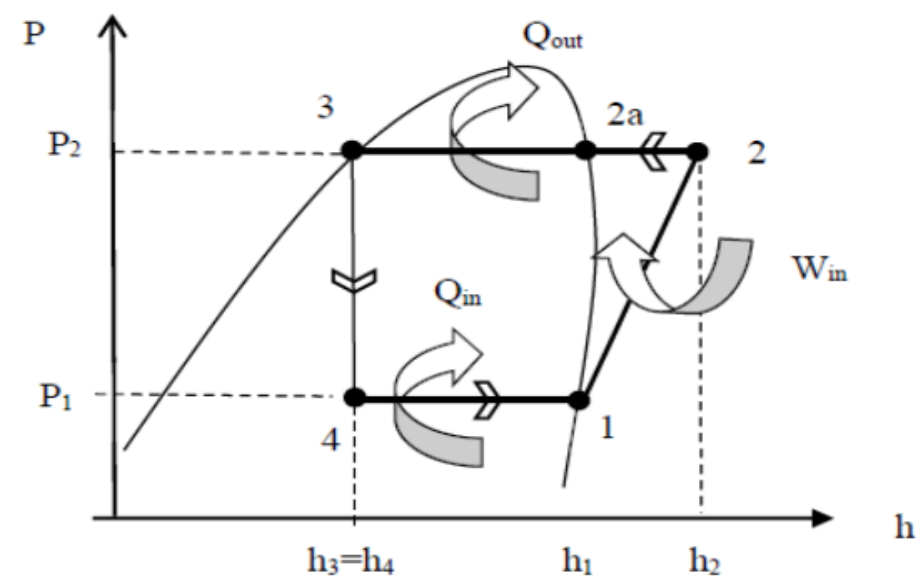

Figure 2. The vapor compression cycle in the p-h diagram 


\section{International Journal of Applied Sciences and Smart Technologies}

Volume 3, Issue 1, pages 83-92

p-ISSN 2655-8564, e-ISSN 2685-9432

The process of the steam compression cycle engine includes: (1) process 1-2: isoentropic compression (2) process 2-2a: desuperheating (3) process 2a-3: condensation or condensation (4) process 3- 4: throttling or lowering pressure isoenthalpy (fixed enthalpy) (5) 4-1 process: evaporation or refrigerant evaporation process. During the evaporation process, heat flows from the ambient air around the evaporator to the refrigerant that flows in the evaporator pipe. The amount of heat absorbed by the mass-refrigerant unity evaporator is $Q_{\text {in }}$. The amount of heat released by the mass-refrigerant unity condensor is $Q_{\text {out }}$. During the compression process, the compressor works to increase the refrigerant pressure, from low pressure to high pressure or from the evaporator working pressure to the condensor working pressure. Work done by the compressor During the desuperheating and condensation process, heat flow occurs from the condensor out into the environment around the condensor. The mass-refrigerant unit is equal to $W_{\text {in }}$. The amount of work done by the compressor is the power supplied by a power source or from electrical energy to the massrefrigerant unity compressor. In this steam compression cycle, the subcooling and superheating processes are eliminated.

The amount of heat absorbed by the mass-refrigerant unity evaporator $\left(Q_{\text {in }}\right)$ can be expressed by

$$
Q_{\text {in }}=h_{1}-h_{4} .
$$

The amount of heat released by the mass-refrigerant unity condensor $\left(Q_{\text {out }}\right)$ can be expressed by

$$
Q_{\text {out }}=h_{2}-h_{3}
$$

The amount of work performed by the mass-refrigerant unity compressor $\left(W_{\text {in }}\right)$ can be expressed by

$$
W_{\text {in }}=h_{2}-h_{1} \text {. }
$$

The values of $h_{1}, h_{2}, h_{3}$ and $h_{4}$ are the enthalpy value of the refrigerant when it enters the compressor, the enthalpy of the refrigerant when it leaves the compressor, the enthalpy of the refrigerant when it leaves the condensor and the enthalpy of the refrigerant when it enters the evaporator. 


\section{International Journal of Applied Sciences and Smart Technologies}

Volume 3, Issue 1, pages 83-92

p-ISSN 2655-8564, e-ISSN 2685-9432

The performance (Coefficient of Performance or COP) of the steam compression cycle machine used in wood drying machines with electrical energy is the ratio between the useful energy for mass-refrigerant unity with the amount of energy required for mass-refrigerant unity. The Coefficient of Performance or COP of the steam compression cycle of this electric energy wood drying machine can be expressed by

$$
\operatorname{COP}=\frac{\left(Q_{\text {in }}-Q_{\text {out }}\right)}{W_{\text {in }}} \text {. }
$$

The heat absorbed by the evaporator causes the ambient air that passes through the evaporator to dry, and the heat released by the condensor causes the temperature of the air that passes through the condensor to increase to become hot. In Equation (4), the energy used to drive the fan has not been calculated: the evaporator fan, the condensor fan and the fan in the drying room.

\subsection{Open Air System Wood Drying Machine}

The wood drying machine used in this study uses an open air system. In this open air system, the air used as a wood drying medium is taken from the outside air. The outside air is introduced into the drying room, by first passing through the evaporator and condensor. Outside air can flow in because of the evaporator fan and condensor fan. After the air is put into the drying room, it performs the wood drying process. The air that has been used to dry wood is then flown out of the dryer, and is no longer used.

\section{Research Methodology}

In this section we describe about how this research was carried out among others the research methods and research variations, research flow, equipment used, dried object, and how to collect data.

\subsection{Research Methods and Research Variations}

The research was conducted experimentally. Variations in the study were carried out on the presence of fans in the wood drying room: (a) there was no fan and (b) there were two fans in the wood drying room. 


\section{International Journal of Applied Sciences and Smart Technologies}

Volume 3, Issue 1, pages 83-92

p-ISSN 2655-8564, e-ISSN 2685-9432

\subsection{Research Flow}

The research flow follows the flow as presented in Figure 3.

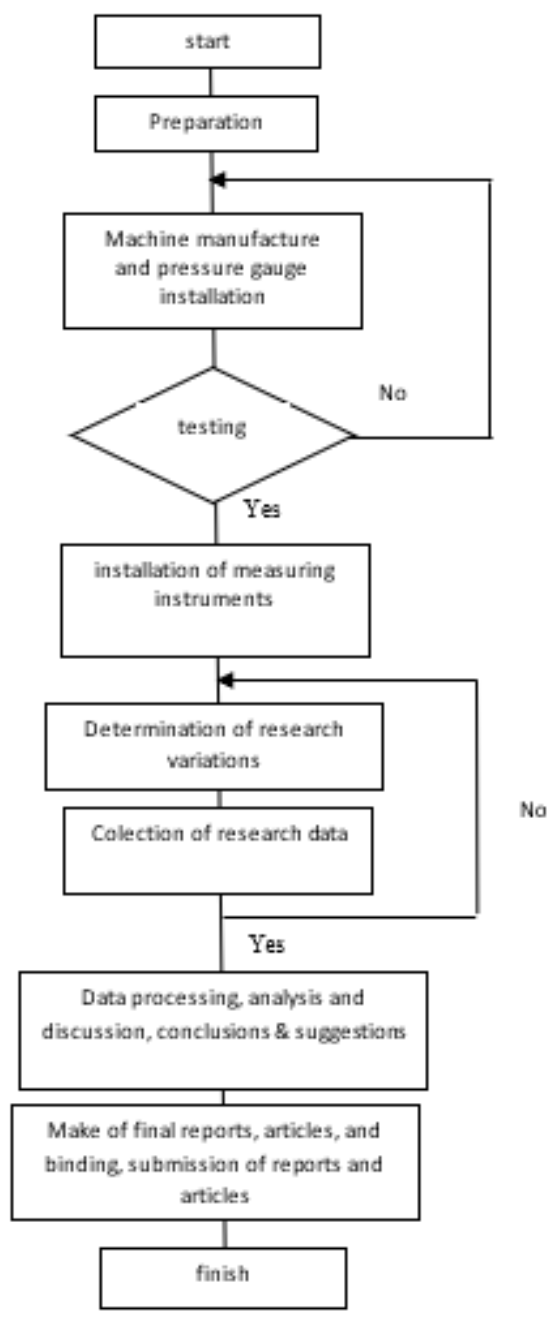

Figure 3. Research flow

\subsection{Equipments}

The rotary compressor power used in the steam-compression cycle engine is $1 \mathrm{HP}$. The other main component, its size adjusts to the amount of compressor power. The compression cycle uses R134a refrigerant. The power per fan used in the wood drying room is 30 watts. The evaporator fan has 17.5 watts of power and the condensor fan has a power of 20 watts. The wood drying machine has a total length of $350 \mathrm{~cm}$, a total height of $180 \mathrm{~cm}$ and a total width of $140 \mathrm{~cm}$. 


\section{International Journal of Applied Sciences and Smart Technologies}

Volume 3, Issue 1, pages 83-92

p-ISSN 2655-8564, e-ISSN 2685-9432

\subsection{Dried object}

The object that was dried was a wet sengon wood board with an initial moisture content of $29.6 \%$. The wet wooden planks are dried until they have a moisture content in the wood of $10 \%$. The size of the wooden boards to be dried is uniform, has a length of $2 \mathrm{~m}$, a width of $20 \mathrm{~cm}$ and a thickness of $2 \mathrm{~cm}$. Number of board to dry: 70 boards of wood, for one drying. Wooden boards are arranged on racks, shelves are arranged from bottom to top, one shelf contains 5 wooden boards (horizontal direction), there are 14 shelves arranged.

\subsection{Data collection}

Before entering wet wood, the engine is started first. Data collection starts after all the wet wood is in the drying room, and the door to the wood drying room has been closed. Data collection was stopped after all sengon wood was dry (having moisture content in the wood $<10 \%$ ). Measurement of moisture content in wood using a digital moisture meter. Temperature and humidity data were measured using a thermocouple and hygrometer. Meanwhile, for low pressure (evaporator working pressure) and high pressure (condensor working pressure) in the steam compression cycle using a pressure gauge. The enthalpy data is taken from the P-h diagram.

\section{Results and Discussion}

Figure 4 presents the drying process of sengon wood boards from time to time, from the initial condition of the wet wood boards with an average moisture content of $29.6 \%$ to an average moisture content of $10 \%$. It appears that the presence of a fan in the wood drying room affects the drying time of the wood. The existence of a fan, causes the airflow to be faster and the drying time is faster. In other words, the drying time of wood is affected by the speed of air flow in the drying room. The greater the speed of air flow across the wood surface, the faster the drying time. If there is no fan in the drying room, it means that the air flow that occurs in the drying process is only caused by the evaporator fan and condensor fan.

From Table 1 and Figure 4, information is obtained, if there is no fan in the drying room, the wood drying time is 49.9 hours, and if there is a fan, the wood drying time is only 42.6 hours. The use of 2 fans can shorten the drying time by about 7.3 hours or 


\section{International Journal of Applied Sciences and Smart Technologies}

Volume 3, Issue 1, pages 83-92

p-ISSN 2655-8564, e-ISSN 2685-9432

speed up the drying time by $14.6 \%$. Even though it is able to shorten the wood drying time, the wood drying process requires additional electrical power which is used to drive 2 fans. The air condition when there are 2 fans in the drying room is presented in Table 2. Further research is needed, regarding the effect of adding a fan on the optimal work of a wood drying machine.

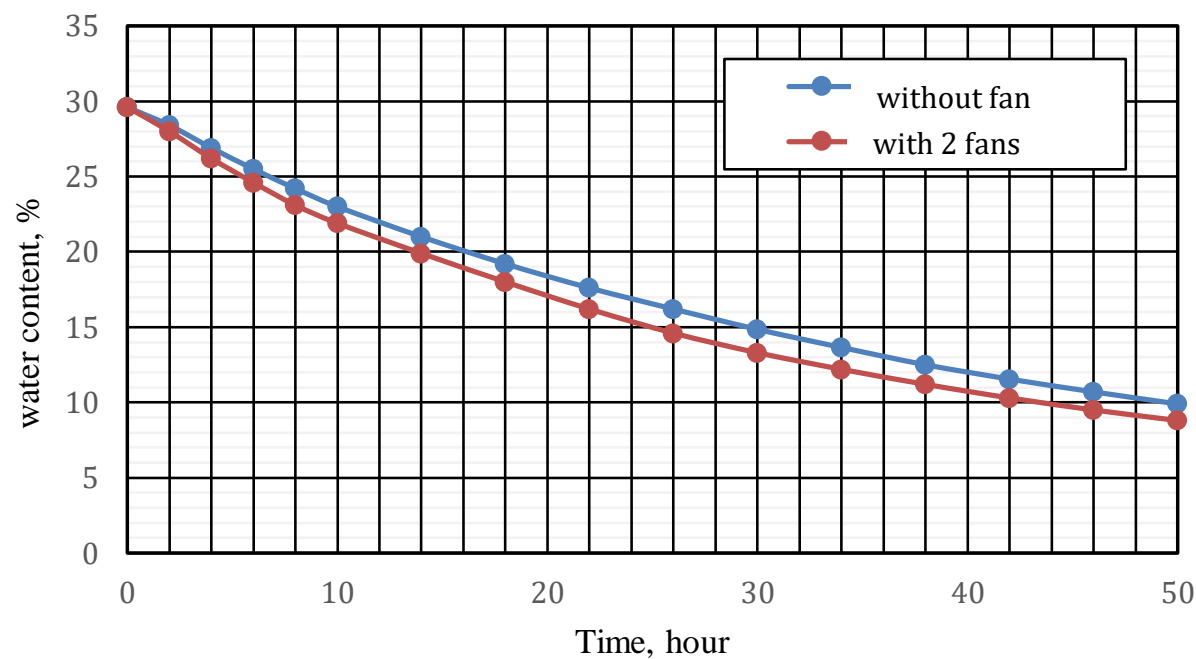

Figure 4. Moisture content in sengon wood from time to time

Table 1. Drying time of sengon wood

\begin{tabular}{llc}
\hline \multirow{2}{*}{ No } & \multicolumn{1}{c}{ Research Variations } & Drying time $\mathrm{t}$ \\
\cline { 3 - 3 } 1 & There is No fan in wood dryer room & $\mathrm{t}$ (hour) \\
2 & There are 2 fans in the wood dryer room & 49,9 \\
\hline
\end{tabular}

Table 2. Air conditions in and out of the sengon wood drying room

\begin{tabular}{cccccc}
\hline \multirow{2}{*}{$\begin{array}{c}\text { No } \\
\text { Conditions in } \\
\text { the wood drying } \\
\text { room }\end{array}$} & $\begin{array}{c}\text { The air condition exits the wood } \\
\text { drying room }\end{array}$ & \multicolumn{2}{c}{$\begin{array}{c}\text { The air condition enters the } \\
\text { wood drying room }\end{array}$} \\
\cline { 3 - 6 } & & $\mathrm{T}_{\mathrm{db}}\left({ }^{\circ} \mathrm{C}\right)$ & $\mathrm{RH}(\%)$ & $\mathrm{T}_{\mathrm{db}}\left({ }^{\circ} \mathrm{C}\right)$ & $\mathrm{RH}(\%)$ \\
\hline 1 & There is not fan & 30 & $68 \%$ & 40,5 & 31 \\
2 & There are 2 fans & 28 & $73 \%$ & 40 & 32 \\
\hline
\end{tabular}

With increasing air flow velocity, the greater the air flow across the wood. The greater the air flow, the greater the ability of air to take water from the wood. Because the air system is made open, the air that has passed through the wood is immediately flown out of the drying chamber, and the air is replaced with new air coming from the condensor. 


\section{International Journal of Applied Sciences and Smart Technologies}

Volume 3, Issue 1, pages 83-92

p-ISSN 2655-8564, e-ISSN 2685-9432

The new air used to dry the wood is dry and the temperature is high enough. The component of the vapor compression cycle which functions to make the air dry is the evaporator and the component that makes the air a high enough temperature is the condensor.

Having 2 fans in the wood drying chamber does not have much impact on the characteristics of the steam compression cycle machine. The air fan has more impact on the evenness of the air flow velocity that occurs in the drying room. More even and easier to get out of the drying room. Because the air flow system is open, the airflow flowing through the evaporator and condensor is more dominant due to the evaporator fan and condensor fan only. However, the work of the evaporator fan and the condensor fan work becomes lighter with the fan in the drying room. Average characteristics of the steam compression cycle machine on a wood drying machine are presented in Table 3.

Table 3. Performance of steam compression cycle machine on wood drying machine (Sengon wood drying)

\begin{tabular}{ccccccc} 
No & $\mathrm{T}_{\text {evap, }}{ }^{\circ} \mathrm{C}$ & $\mathrm{T}_{\text {kond, }}{ }^{\circ} \mathrm{C}$ & $\mathrm{Q}_{\text {in }}(\mathrm{kJ} / \mathrm{kg})$ & $\mathrm{Q}_{\text {out }}(\mathrm{kJ} / \mathrm{kg})$ & $\mathrm{W}_{\text {in }}(\mathrm{kJ} / \mathrm{kg})$ & $\mathrm{COP}$ \\
\hline 1 & 6 & 50 & 130,3 & 157,3 & 27 & 10,65 \\
\hline
\end{tabular}

\section{Conclusion}

The results of the research for the electric energy wood drying machine steam compression cycle of this closed air system are: (a) if there are 2 fans in the drying room, the time required to dry the sengon wood planks is 42.6 hours, whereas if there is no fan for 49.9 hours; (b) The Coefficient of Performance or COP of the wood drying machine with an average electrical energy of 10.65 ; (c) the air enters the drying room when there are 2 fans, has a dry ball air temperature of $40^{\circ} \mathrm{C}$ with $32 \% \mathrm{RH}$ and the dry ball air temperature out from $28^{\circ} \mathrm{C}$ drying chamber with $73 \% \mathrm{RH}$. This research can be developed to determine the relationship between the condensor working temperature and the COP and the time required for the drying process or it can be developed by looking for the relationship between the working temperature of the evaporator and the performance of the dryer and the time required for the wood drying process. 


\section{International Journal of Applied Sciences and Smart Technologies}

Volume 3, Issue 1, pages 83-92

p-ISSN 2655-8564, e-ISSN 2685-9432

\section{References}

[1] T. Mitsunori, "Dehumidifying and heating apparatus and clothes drying machine using the same", European Patent Specification, EP 2468948 B1, 27.11.2013, 2013.

[2] Balioglu, "Heat Pump Laundry Dryer Machine", Patent Application Publication, Pub. No: US 2013/0047456 A1, April 2013.

[3] Bison, "Heat Pump Laundry Dryer and a Method for Operating a Heat Pump Laundry Dryer", Patent Application Publication, Pub. No: US 2012/0210597 A1, 2012.

[4] W. Kusbandono and P.K. Purwadi, "Pengaruh Adanya Kipas yang Mengalirkan Udara Melintasi Kondensor terhadap COP dan Efisiensi Mesin Pendingin Showcase." Prosiding Seminar Nasional XI Rekayasa Teknologi Industri dan Informasi, 313-317, 2016.

[5] W. Kusbandono and P.K. Purwadi, "COP Mesin Pendingin Refrigeran Sekunder." Jurnal Penelitian, 19 (1), 79-86, 2015. 